\section{セロフアン厚層塗抹法による犬の 䔬便検査について}

\section{阿久沢実*}

最近寄生虫卵を検索する方法として，セロフアン紙を 応用した人屎厚層塗抹法が公表され，その虫卵検出率は 従来の集畉法に比較して大差なく，ときにはそれよりる 高い検出率を示したという報告もみられている．

私はこの方法を大の検便に応用した結果, 操作も簡易 で虫卵検出率も普通の塗抹法にくらべて高く，とくに， 土砂の混入が多いので好適な標本の作製が困難な犬の䔬 便を対象とした場合に好都合で，獣医臨床上その実用的 な価値があると思われるので，その手技について述べあ わせてそれによる検查成績を, 従来の方法によるとれと 対比して参考汇供したいと思う。

\section{セロフアン厚層塗抹標本の作り方}

載せガラス中央に検体 $50 \mathrm{mg}$ (原法には正確江秤量す るとあるが，大体マッチ棒の頭大の量でよい）を採取 し, 次ぎの液を添加して妻揚子かマッチの軸でよく混和 し，その上に大きさ $2 \mathrm{~cm} \times 5 \mathrm{~cm}$ に切ったセロフアン紙 をのせ，抽指頭で軽く圧しながら楕円形に展げて厚層標 本を作り，30分ないし60分以内に全視野について鏡検す る.

添加する液の作り方 :

$$
\left.\begin{array}{ll}
\text { グリセリン } & 1 \\
\text { 常 水 } & 2
\end{array}\right\} \text { 混合する }
$$

これに $0.1 \%$ の割に色素 malachite green を加兄る.

また，同一の糞便について普通塗抹法（カブセガラス $18 \mathrm{~m} / \mathrm{m}$ を使用した標本 3 枚について検查）および集卵 法（稀塩酸・エーテル法）を行なった。

\section{検 查 成 績}

セロフアン厚層標本について検索した結果は表 1 亿示 すと括りであって，22例中，回虫卵 5 例 $(23 \%)$, 銁虫卵 12 例 $(55 \%)$ ，鞭虫卵10例( $45 \%)$ にとれぞれ陽性の結果が えられた。この成績を他の検査法によるそれと比較する と, 普通塗抹法に技いて, 回虫卵の検出頻度はセロフア ン厚層法と同様であるが，銁虫卵および鞭虫卵の検出状 況は，セロフアン厚層法にはるかにおよばないといら成 績がえられた。

次ぎの集卵法汇よる結果をみると, 回虫卵ではセロフ アン厚層法とょく一致するが，鈎虫卵では集畉法で10例 に，セロファン厚層法で12例に陽性，鞭虫畉では集畉法 で8例に, セロファン厚層法では10例にそれぞれ虫卵陽 性であった。

このような結果からみるとセロフアン厚層法は普通塗 抹法にくらべて，きわめて高い虫卵検出率を示している ことがうかがわれるし，また集卵法にくらべても決して 拈とらない結果がみられ，とき沈それよりも高い検出 率を示したといら先人の報告を裏書きした成績が党られ た。

\section{おわり}

セロフアン厚層塗抹法を犬の検便に応用し，その絬果 を普通塗抹法叔よび集卵法による成績と比較したところ 普通塗抹法による虫卵検出率はセロフアン厚層法にくら ベてはるか打とり，李た本法は集畉法に比較しても少 しも拉とらない方法であることを知ることができ，その 上, 標本の作製が容易で, 小動物の臨床検查に応用して きわめて価值の高い方法であると信ずるので，広く一般 飞試用されることを願うものである.

ご校閲を賜かった清水重矢教授湠謝いたします。

第 1 表 各検查法別にみた虫卵検出成績

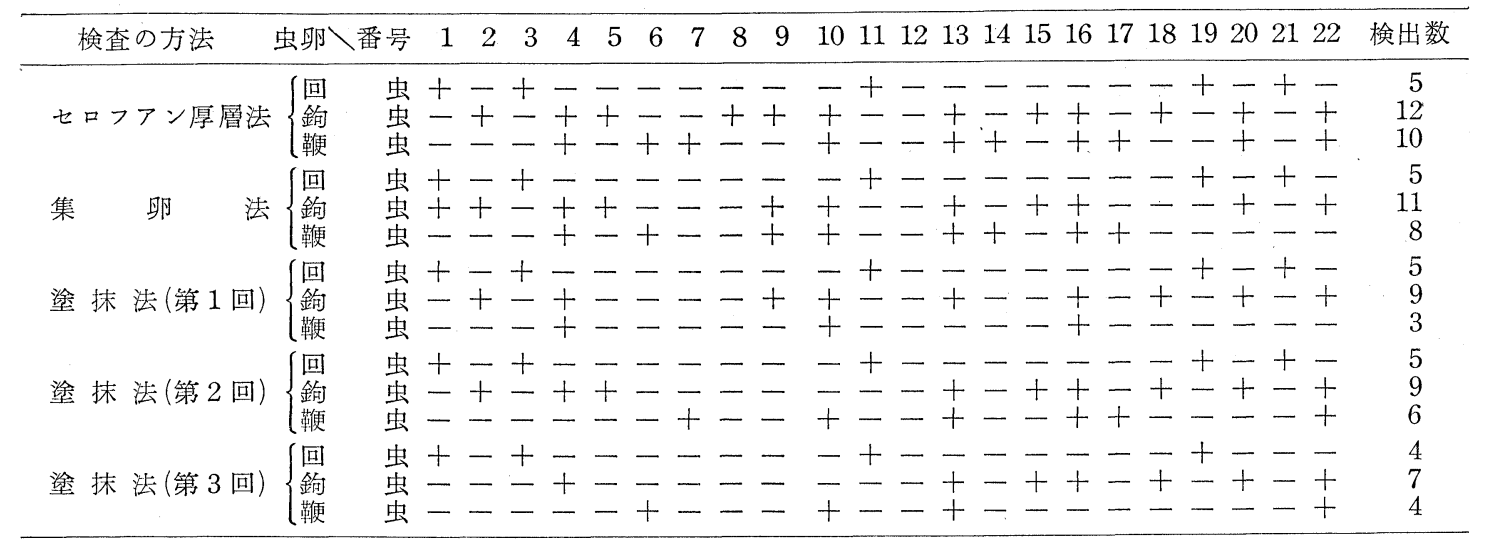

* 日本獣医畜産大学医動物学教室

日獣会誌

15 (1962)
文献 1) 加藤勝也: 寄生虫学雑誌, $7,8,239$ (1958). 2) 街 智：日医大誌, $27,6,259$ (1960). 